\title{
Self-Assessed Digital Competences of Romanian Teachers During the COVID-19 Pandemic
}

\section{OPEN ACCESS}

Edited by:

Jin Su Jeong,

University of Extremadura, Spain

Reviewed by:

Kamariah Abu Bakar,

National University of Malaysia,

Malaysia

Mariana Cernicova-Buca,

Politehnica University of Timişoara,

Romania

Stamatios Papadakis,

University of Crete, Greece

John Mark R. Asio,

Gordon College, Philippines

${ }^{*}$ Correspondence:

Otilia Clipa

otilia.clipa@usm.ro

tThese authors have contributed equally to this work

Specialty section:

This article was submitted to Educational Psychology, a section of the journa

Frontiers in Psychology

Received: 06 November 2021

Accepted: 04 February 2022

Published: 01 March 2022

Citation:

Hatos A, Cosma M-L and Clipa O (2022) Self-Assessed Digital Competences of Romanian Teachers During the COVID-19 Pandemic. Front. Psychol. 13:810359. doi: 10.3389/fpsyg.2022.810359

\section{Adrian Hatos ${ }^{1 \dagger}$, Mirela-Lăcrimioara Cosma ${ }^{1 \dagger}$ and Otilia Clipa ${ }^{2 * \dagger}$ \\ ${ }^{1}$ Department of Sociology, University of Oradea, Oradea, Romania, ${ }^{2}$ Department of Science of Education, Stefan cel Mare University, Suceava, Romania}

Studies on the determinants of school results have shown that they depend largely on the context of learning. Concerning the pandemic, teachers have been forced to find online teaching methods, which leads us to the central issue of this study of whether the effectiveness of online education depends on teachers' digital skills. Therefore, in this study, we analyzed the perceived digital competences of Romanian pre-tertiary cycle teachers about their professional status, school location, gender, age, taught field, and prior participation in training for online teaching. Using data from 3,419 self-completed questionnaires in an online survey of teachers performed at the beginning of the global lockdown in March 2020, we have built two reliable measures of perceived digital skills, namely the Self-Assessed Multimedia and Online Skills Score (SMOS) and the SelfAssessed Digital Office Skills Score (SDOS), which were the dependent variables in our study. Hierarchical linear regressions were used to test the hypotheses regarding the variations of dependent variables, measuring the two concepts of self-assessed digital skills (SMOS and SDOS). These concepts underlined that both decrease with age and are positively affected by prior attendance at training sessions for online teaching skills and by having ICT and informatics as a taught subject field. However, teachers of all specialties are relatively significantly less skilled in this field. The most important results concern the impact of gender and professional status on the teachers' selfassessed digital competences. In summary, it appears that self-assessed office digital skills are a specialism demonstrated mainly by female teachers, while multimedia and online skills are perceived by teachers to be a "male" domain. Simultaneously, net of the other variables, a higher status within the teaching profession correlates positively with perceived office digital skills. Lastly, implications for future research, as well as for educational interventions and policies, are discussed.

Keywords: digital competences, teachers perceived digital skills, Romanian education, teachers, teachers training

\section{INTRODUCTION}

Fundamentally, all education systems aim to shape Students' personalities, knowledge, and skills into their very best forms. During the pandemic period, these core aims were significantly challenged by schools' closures and the generalized shift to digital means of communication and information-sharing (Ali and Kaur, 2020; Schleicher, 2020). For the first time in decades 
of technological advances, entire societies were forced to maximize their ICT infrastructure and abilities to meet the basic objectives of schooling, and other societal needs (OECD, 2020a,b; Maněnová et al., 2021).

The impact of the use of technology on student outcomes is dependent on its integration in the classroom to support teaching and learning practices. Teachers' digital competences are crucial to optimize new technologies in the classroom (Engen and Engen, 2019), therefore, it is important to understand that teachers' digital skills are related to Students' performance in digital learning conditions (OECD, 2019a), in this case, the COVID-19 pandemic.

Highly digitally skilled teachers cannot only do a better job in creating and distributing content as well as in communicating with their pupils, but they can also increase the levels of academic achievement. This rich communication from teacher to student is critical for student outcomes: studies have shown that students who have high levels of engagement have better grades and display better personal conduct, as well as higher levels of selfesteem and compliance with socially appropriate behaviors (Lam et al., 2014). Furthermore, it is associated with high rates of school completion (Veiga et al., 2012).

Perceived digital skills, of teachers and students alike, have played a crucial role during this pandemic period as an individual's assessment of their ICT skills is a significant mediator in terms of how effectively they are put into practice (Winstone et al., 2021).

However, for entire systems of education, including the Romanian system, it was a huge challenge to rapidly shift from on-site teaching and learning to online didactic activities (Lim, 2020), using technology to facilitate and enhance Students' performance and wellbeing. Issues of access (e.g., access to computers, internet, and even digital skills development courses), along with gaps in both Students' and teachers' digital skills and a lack of confidence or overconfidence inabilities of both students and teachers raised formidable obstacles against the delivery of education during the pandemic (Ali and Kaur, 2020; Schleicher, 2020). On the other hand, this uniquely challenging period allowed teachers to develop their digital skills and practice teaching by utilizing apps, software, videos, and films, when the online environment was the only option for keeping in touch with their students (Saavedra, 2020).

In this article, we focus on one of the aspects most critical for teachers performing in online education: their perceived digital skills. To meet this objective, we build several hypotheses concerning teachers' self-perceived digital skills and test them on a large data set produced through an online survey carried out during the pandemic.

The paper will discuss the context of Romanian education and access to ICT in Romanian schools, then the concept of teachers' perceived digital skills (including their relationships with actual digital performativity and how it is operationalized for the specific case of online education). Subsequently, a set of hypotheses about the variation of teachers' digital skills will be identified, based on a review of the existing literature. Then, in the empirical part of the article, we will discuss our two indices of perceived digital skills and the results of hierarchical multiple regressions in which these two indices are used as dependent variables to test our hypotheses.

\section{The Relevance of Teachers Perceived and Actual Digital Skills for Student Achievement via Online Education}

Students' academic results are dependent on contextual factors, such as educational materials, the educational and cultural background of a Student's family, how students spend their free time, and other psycho-climatic factors. It is almost selfevident that the effectiveness of online education is significantly dependent on teachers' digital competences. Innovative teaching using ICT requires much more than basic ICT skills. Teachers have the power to transform ICT in learning and communication technology, as teachers' perceived usefulness, information processing skills (the skills of information access, information usage, and information management), and information ethics could predict teachers' competence to develop Students' information literacy (Wu et al., 2022); however, both teachers and their students must first realize the potential of ICT to impact learning and to transform education (Napal-Fraile et al., 2018).

Researchers highlighted the importance of teachers' digital competences, computer provisions, and electronic devices in online education, arguing that ICT is facilitating the establishment of a skilled community and workforce for a knowledge society (Malik, 2018). As such, we can assume that the higher the level of teachers' digital skills, the easier the information transfer. Likewise, the higher the volume of information acquired, the more accurate the appreciation.

More recently, Røkenes and Krumsvik (2014) reviewed a vast number of studies on teachers' use of ICT in the classroom, revealing that the effectiveness of implementing ICT in schools may partly rely on Students' digital competence (Røkenes and Krumsvik, 2014; Wu et al., 2022) as well as on how effectively teachers can implement and use ICT for teaching and learning. Indeed, strong correlations have been found between teachers' digital competence and Students' subject learning outcomes in Norwegian secondary schools (Røkenes and Krumsvik, 2014). ICT in education can be used for a variety of different purposes, such as active teaching and learning through Students' involvement (Ghavifekr and Quan, 2020), improving Students' understanding of key concepts or developing content knowledge and specific abilities, as well as a correlating improvement in their learning results (Furman et al., 2019). In this regard, Isteniè (2021) builds a strong argument that feedback with a supportive function is essential in a time when students and teachers are working remotely.

\section{The Importance of Attitudes Toward Information and Communication Technologies and Perceived Information and Communication Technologies Skills}

Regarding technology adoption in the classroom, some studies have shown that the successful implementation of educational technologies is dependent on the attitudes of educators toward ICT, who eventually determine how they are used in their 
teaching practice (Asad et al., 2020; Ifinedo et al., 2020; Hofer et al., 2021). In this context, teachers' perceived ICT competences play a significant role. Birgin et al. (2020) highlighted that educators' attitudes toward computer technologies are also related to their perceived computer competence. Furthermore, teachers perceive digital competence as a significant predictor of their attitudes toward computers (Lucas et al., 2021). In the same manner, researchers illustrated how several educators, whose perceived computer competence was low, also showed negative or neutral attitudes toward the use of ICT in education in general. Moreover, it has been found that the more highly teachers rate their digital competence, the more likely they are to use ICT in their work (Sundqvist et al., 2020), as illustrated by Malaysian teachers whose digital competency and confidence level in using ICT are in a positive relationship (Tasir et al., 2012). However, in other studies, the limitations in teachers' ICT knowledge have caused anxiety about using ICT in the classroom, and thus, they are not confident in using it to teach (Arkorful et al., 2021; Huang et al., 2021; Šabić et al., 2021), namely in front of a class of children who are perhaps more digitally literate than they are (Van Mechelen et al., 2021). Keeping this in mind, teachers, who are not confident in using ICT in their teaching, will encounter difficulties in preparing their students to be confident in the use of ICT for themselves (Starčič et al., 2016), but at the same time, as Willems et al. (2021) found out, pre-service teachers' selfregulation and mastery approach goals are strengthened when using case studies (even examples) that are authentic.

\section{Context: The Advance of Digitalization and Internet Penetration Rate in Romania}

Romania's internet penetration rate has been increasing, both in terms of access and terms of use, reaching a rate of $80 \%$ internet penetration by January 2020 (Hootsuite and Social, 2019). Additionally, the 2018 Digital Economy and Society Index (DESI) score for Romanian internet users shows growth in penetration rates in the last 5 years (DESI, 2018a,b). Scores are shown from a minimum of 0 to a maximum of 100 , and on this chart, the scores are represented by a line. As illustrated in Figure 1 below, having access to the internet does not necessarily equate to using the internet.

\section{Digitalization and Internet Penetration in Romanian Schools}

Romanian schools have gradually undergone the digitalization process. In 2001, a government program called Computerized Educational System [Sistemul Educaţional Informatizat (SEI)] was launched to computerize the Romanian education system. Another government-level target was to achieve the objectives of the National Plan for European Union membership by equipping all pre-university education institutions with computer laboratories, based on Government Decision No. 1108/25.09.2003 (Noveanu et al., 2008).

The inter-county differences in Romania's school digitalization processes are closely related to regional development and GDP per capita between the counties. To address these discrepancies, the RO-NET project (MCSI, 2011) was launched in 2011 to build national broadband infrastructure in socio-economically disadvantaged areas by using structural funds. Eurostat (2020) from different regions show a negative correlation between GDP per capita/counties and digitalization process, except for in the West of the country (where GDP per capita is $€ 10,800$ ) and in the Northwest (where GDP per capita is €9,800), as together they sum up several 128 localities who benefit the most from broadband internet. In the poorest region of Romania (the North East according to Eurostat 2018, where GDP per capita is €6,600) 115 localities benefit from broadband internet. In the richest region, Bucharest-Ilfov, according to Eurostat 2018 (where GDP per capita is $€ 24,000$ ), a smaller number of localities benefit from broadband internet (i.e., 84). In 2005, according to the Bologna Process, it was compulsory to include a special course for ICT in education in pre-service teacher training. With increasing access to computers and the internet, teachers began to take advantage of technology to encourage students to learn; however, computer science, as a subject, became mandatory only in 2017, based on an order issued by the Minister of National Education-Ministerul Educaţiei Naţionale (MEN) no. 3393/02.28.2017. In 2019, MEN launched a national project for teachers CRED (55.000 teachers' participants) who follow the in-service teacher training courses for updating didactical strategy, intending to adopt the national curricula for primary and secondary level and to create the Open Educational Resources. In 2020, the project transformed, with all activities shifted from being on-site to being online and teachers trained to use virtual tools for education, as well as to share these experiences with their colleagues (MEC, 2014-2020).

In summary, in Romania, several initiatives are in place for inservice teacher training in the special and high current areas of the introduction of digital tools in education and increasing the digital competences of Romanian teachers.

\section{LITERATURE REVIEW}

\section{Concept: Teachers' Actual Digital Abilities and Perceived Digital Abilities}

Bringing digital technology into the classroom means more challenges and responsibilities for teachers. Besides the professional competences that already exist, digital competences have become a new necessity to handle teaching, guidance, and assessment. In this context of teachers' digital competence, four key concepts highlight the need to handle technology: computer literacy, media literacy, digital literacy, and digital competence (Røkenes and Krumsvik, 2014).

As a general definition, a teacher's digital competence is their proficiency in using ICT in a professional context with good pedagogical judgment. The focus here is on pedagogy and the subject itself, with technical skills being part of the general digital competence concept (Cabero-Almenara et al., 2020). In the context of digital competence, Janssen et al. (2013) recommend separating use and skills as two facets of digital competence: general vs. "pure" digital competence (i.e., it is difficult to identify what is "pure" digital competence and what is derived from other domains/cognitive processes); 


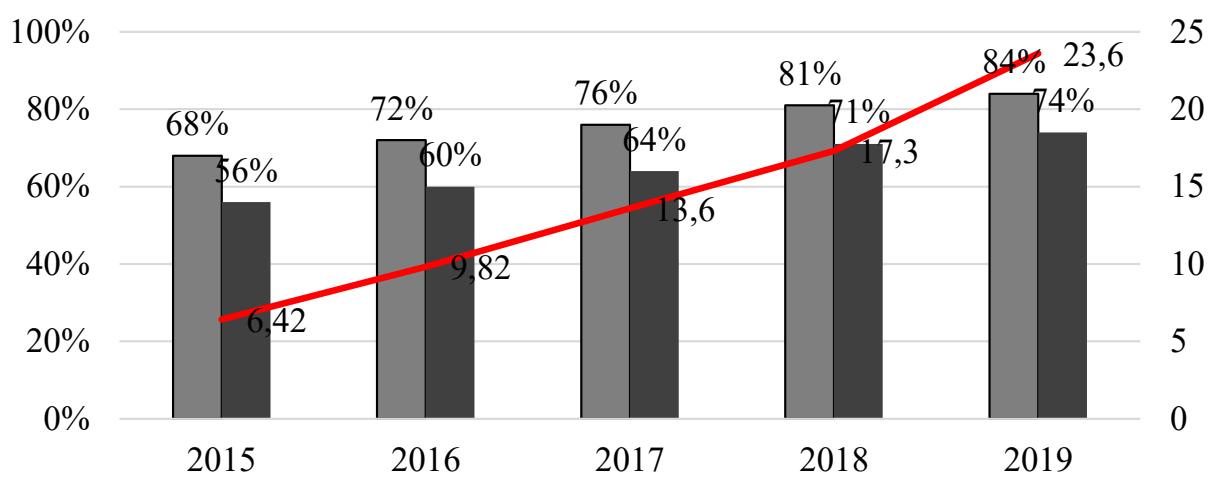

$\square$ Access to internet by Households $\square$ Internet Use by Individuals

—Internet users by DESI scores

FIGURE 1 | Internet penetration in Romania in the last 5 years (DESI, 2018a; Eurostat, 2020). The Digital Economy and Society Index (DESI) is a composite index that summarizes relevant indicators on Europe's digital performance and tracks the evolution of EU Member States in digital competitiveness. DESI Indicators: connectivity, human capital, use of internet services, integration of digital technology, digital public services (DESI, 2018b).

digital competence vs. values and attitudes (i.e., ethics and social values are not necessarily considered as a part of digital competence) (Mâţă et al., 2020); and digital competence vs. digital preference. Indeed, experts recommend drawing a clear line between digital competence and personal preference, which is the individual's choice or desire to use a particular digital technology (Vasileva-Stojanovska et al., 2015).

More specifically, digital abilities are classified by Van Dijk (2020) as operational abilities (i.e., operating hardware, software, and networks); formal abilities (i.e., understanding and managing formal characteristics of a computer and a network, as well as their structures: files and hyperlinks); informational abilities (i.e., searching, selecting processing, and evaluating information from specific sources on computers and networks); and strategic abilities (i.e., using the afore-mentioned information as a way to achieve specific objectives for improving someone's social position). These conceptualizations of digital abilities reveal the broad array of knowledge, attitudes, and skills involved in ICT.

Based on our consultation with teachers during the pandemic, the sudden shift to online teaching brought about by the school closures meant that some digital skills proved to be critical, such as the ability to communicate using email and messaging applications, the ability to manage a website, use digital office suites to edit documents, create educational videos and/or to stream video sessions followed by uploading their recordings, and use distance learning platforms. Due to their immediate practical value demonstrated during the rapid migration to teaching online which took place in 2020, we use these specific tasks as a basis for measuring self-assessed digital teaching competences.

\section{The Relationship Between Actual Digital Competences and Perceived Digital Competences}

Subjective self-assessment can be defined as an estimation of how skilled or competent an individual is regarding a particular skill, ability, or characteristic (Maderick et al., 2016); therefore, in our field, perceived digital competences is an estimation of how digitally skilled or competent teachers are regarding a particular digital skill, ability, or characteristic. This concept correlates with that of digital self-efficacy, building on Bandura (1994) more general conceptualization, which defines self-efficacy as people's beliefs about their abilities to perform in activities that influence their lives and, thus, is a capacity that determines how they feel, think, motivate themselves, and behave. Therefore, even if these beliefs do not directly determine whether or not success will be achieved in practice, they still have an influence that affects what individuals choose to do, how they do it, and thus indirectly whether or not they have a chance at succeeding in a particular task (Guo et al., 2015; Brickman, 2021). Wong et al. (2021) in their research on secondary school teachers' psychological status and competences in E-teaching during COVID-19, showed a negative relationship between psychological status and e-teaching competences $(-0.286, p<$ 0.01 ), as well as reported a negative relationship between the dimension of psychological status and competences in e-teaching.

"Computer anxiety (ICT anxiety) is a generalized emotion of uneasiness, apprehension, the anxiousness of coping, or distress in anticipation of negative outcomes from computerrelated operations" (Chang, 2005, p. 715). It is "the feeling of discomfort when using computers (technology more broadly in the context of our study)" (Awofala et al., 2017, p. 92). Indeed, teachers' ICT anxiety is one of the main obstacles to integrating ICT into their education practice (Saxena et al., 2019). In the context of professionals, researchers have found that computer anxiety has a strong negative effect on computer-related activities, such as computer skills, intention to use computers, attitudes toward computers, and perceived usefulness of computers/ICT (Aktag, 2015; Awofala et al., 2017, 2019). Furthermore, Awofala et al. (2019) found that computer anxiety correlates negatively with self-efficacy. 
In certain contexts, perceived digital competences can prove to be a rather valid indicator of actual digital skills (Porat et al., 2018). It does not replace actual behaviors and activities measured in objective terms but captures information on issues and events of the aspect of reality under investigation that could not otherwise be obtained (Mazziotta and Pareto, 2012). Furthermore, self-assessments may depend not only on the objective situation (in this case the actual digital skills possessed by Romanian teachers) but also on the reporting style, which may lead to erroneous conclusions about the actual digital literacy of respondents (Černochová et al., 2020). Nevertheless, researchers show that, regardless of the skills/competences assessed, individuals tend to overestimate their abilities. Maderick et al.'s (2016) review shows that the expertise on the material being tested; the level of difficulty of the material; the specificity of the ability being evaluated; the desirability of the particular skill or ability; gender differences; possible cultural differences; and individual differences in ability are the main factors that lead to erroneous estimation of one's abilities. It has also been suggested that individuals with low levels of expertise or training will tend to overestimate their knowledge and skills in their given domain, simply because they are unaware of their level of competence (Maderick et al., 2016). This may apply to digital competences as well: Individuals who do not have or do not know the level of their digital knowledge and skills may tend to overestimate or underestimate the level of their digital skills. In contrast, Pavić and Černja (2019) found that those who have a low level of digital skills are aware of this and do not exaggerate their self-assessment as much as those who are aware of possessing a higher level of digital skills. This comparative lack of false claims is possibly due to a high level of motivation and dedication to learning how to improve. Therefore, teachers must correctly measure their digital skills to know the level from which they start in online teaching, but currently, there is no known method by which this would be possible in Romania.

However, in existing research, any form of subjective selfassessment, when compared with more objective methods, tends to demonstrate some degree of inaccuracy (Maderick et al., 2016); however, if considered in conjunction with other, more objective means, self-assessment may prove to be useful for teachers in reflecting upon their competence, skills, and knowledge, therefore aiding them in adjusting their perceptions and attitudes regarding technology throughout their professional practice (Huang and Liang, 2015; Maderick et al., 2016). For example, in Khokhar and Javaid's (2016) study, while the surveyed teachers believed that they were using ICT effectively, their students reported that their ICT use was not creative or innovative, and instead wanted them to create authentic teaching and learning classroom experiences. These Students' wishes are an important source of guidance as it has been found that their perceived digital competence and attitudes toward using digital technologies significantly and positively influence their engagement in the learning process (Huang and Liang, 2015).

By way of a conclusion, as Shrauger and Osberg (1981) said, it is unwise to assume that individuals can accurately assess their skills and abilities because they are fundamentally unaware of these capacities on an objective level and tend to present themselves in what they consider to be a socially desirable way. Therefore, in the context of this paper, the concept of "perceived digital competences" refers largely, but not entirely, to the actual digital skills possessed by Romanian teachers as the core of the effective ICT performance required to ensure the positive impact of digital teaching.

\section{Indicators of Teachers' Digital Competences}

There is no bounty of literature on either the predictors of teachers' ICT skills or on their self-perception of these skills. According to literature reviews, teachers' acquisition of skills for use in online environments are conditioned by infrastructure; ICT devices available in the school; training in digital applications; cognitive skills and socio-emotional skills (Bacter et al., 2021), "supported by effective lifelong learning systems" (OECD, 2019b,c,d); school environment; academic engagement; and appropriate ongoing technical support (Hatos, 2019; Akmal et al., 2021). The majority of these predictors refer to the contextual and individual resources available to teachers; however, age and gender are two additional well-known predictors of digital skills.

\section{Age}

At first glance, it may be assumed that younger teachers will have a higher score regarding perceived digital competences than older teachers and that older teachers will have lower actual ICT competences. Indeed, Fernandez-Cruz and FernandezDiaz (2016) found that older teachers (i.e., 56-66 years old) with extensive teaching experience have a much lower ICT competence profile than teachers who are younger and have less experience; they also found that teachers aged between 20 and 25 have the best ICT competence profile. No significant effect of teachers' self-assessed digital skills and age was found by other researchers as well (Drossel et al., 2017; Gil-Flores et al., 2017). However, other studies find that the use of ICT is not influenced by the teacher's age, but by their number of years in service. In $\mathrm{Gu}$ et al. (2013), teachers with less than 5 years of teaching experience were found to use technology less than those with a longer service period.

Research indicates that age might not be a determining factor for digital competences but may contribute to the impact of other age-related circumstantial factors (Law et al., 2008; Majumdar, 2015). However, more recent research has identified a negative relationship between age and ICT use (Juhaňák et al., 2019), or found that digital competence decreases with age (Sundqvist et al., 2020). This idea we intend to carry forward in our study is due to the gap between digital natives and digital immigrants highlighted by researchers (Zenios and Ioannou, 2018; Kesharwani, 2020).

H1: Teachers' self-assessed digital skills are negatively correlated with age.

\section{Gender}

Several studies have suggested that male teachers tend to view themselves (perceived digital skills) as more technologically adept 
and willing to learn about new technology, compared to their female counterparts (Cruz and Díaz, 2016; Ghavifekr et al., 2016; Orser and Riding, 2018). Drossel et al. (2017) reported that a teacher's gender has a significant effect on the frequency of their computer use in classroom settings in three out of the five selected countries: they found that female teachers use computers for instructional purposes more frequently than male teachers in the Netherlands, and male teachers use computers in classroom settings more frequently than female teachers in Poland and Germany. Therefore, it is not yet conclusive whether gender plays a significant role in shaping teachers' ICT use.

H2: male teachers evaluate their digital skills more positively than female teachers.

\section{Context (Rural Schools vs. Urban Schools)}

There are few studies on teachers' perceptions of their ICT skills concerning their location (urban vs. rural), but we can assume that there are differences in their perceived ICT skills if we consider other indicators from previous studies (infrastructure, GDP per capita, quality of education, other social opportunities). For example, Koen et al. (2017) show that there are persistent and growing differences in data infrastructure between urban and rural areas and, if we view urban areas as having higher socioeconomic status, this is an indirect, positive correlation with the availability of ICT resources (Yang et al., 2019). Furthermore, given that teachers in urban schools have been found to use ICT more frequently than those in semi-urban schools (BuabengAndoh, 2019), perhaps we can assume that the frequency is higher than in rural areas as well. According to the same study, urban school teachers receive more training and leadership support than those in semi-urban schools (Buabeng-Andoh, 2019), and, again, perhaps we can expect that it is also more than rural school teachers receive. Hamzah et al. (2021) 's results about the effects of principals' digital leadership on teachers' digital teaching during the COVID-19 pandemic in Malaysia indicate that the level of digital leadership displayed by principals and teachers' digital teaching practice are in a positive correlation and that the ability to plan and organize digital leadership programs is important and can help improve Students' academic performance, despite the COVID-19 pandemic crisis (Karakose et al., 2021a). The last reason for our hypothesis is that urban teachers have been reported to be less anxious about using ICT in the classroom than those in rural areas, a difference found to be especially pronounced among female teachers (Saxena, 2014; Saxena et al., 2019).

H3: Teachers in urban schools evaluate their ICT skills more positively than teachers in rural schools.

\section{Teachers' Qualifications and Status in the Teaching Profession}

Fernandez-Cruz and Fernandez-Diaz's (2016) study of the Madrid teaching community ( $n=1,433$ teachers) reports that teachers working in secondary education have better ICT competences than those teaching in primary education. Additionally, Law et al. (2008) and Celik and Yesilyurt (2013) suggest that the highest percentage of ICT-using teachers are generally more likely to be found among those who have obtained the highest qualification category themselves (i.e., master's degree or above). Moreover, there is evidence that perceived pedagogical competence enhances the use of ICT in pedagogical settings. Furthermore, teachers' self-perceived competence correlates with a higher mean for general ICT use than for pedagogical ICT-use might indicate that teachers are generally more confident about using ICT in everyday situations than in teaching and learning situations (Fu, 2013). Therefore, we want to know whether teachers with high professional status indicators will assess their digital skills more positively than their colleagues, or not.

H4: teachers with high professional status indicators evaluate their digital skills more positively than their colleagues with lower professional certificates, those working in primary schools or secondary schools, or those with a lower professional status.

\section{The Teacher's Subject Field}

There is very little research on the subject field taught as a predictor of teachers' perceived digital skills, although it determines the cognitive and motivational resources required for ICT use, as well as opportunities to practice ICT skills (Sundqvist et al., 2020). However, some studies have revealed that teachers of artistic and practical subjects are less skilled than other subject teachers in using digital teaching materials (Tanhua-Piiroinen et al., 2016; Rucsanda et al., 2021), and that science and technology teachers display higher levels of digital competences (Fernandez-Cruz and Fernandez-Diaz, 2016). However, Al Darayseh (2020) 's study about the impact of the COVID-19 pandemic on modes of teaching science in UAE schools showed that the main challenges for science teachers during the COVID-19 was the absence of hands-on activities, conducting experiments in wet labs, fostering interaction in the online classroom, and managing Students' behavior. Nonetheless, some studies have shown that students living in countries where teachers with more advanced ICT skills are prevalent tend to perform better than their counterparts in a broad range of subjects: i.e., mathematics, reading, and science (Hu et al., 2018); however, there is no clear evidence between the subject field and teachers perceived digital skills. We expect that teachers in computing and informatics evaluate their ICT skills more positively than other teachers due to the time spent on a computer and the specificity of their activity.

H5: teachers, who are active primarily in STEM fields, particularly in computing and informatics, evaluate their ICT skills more positively than other teachers.

\section{Impact of Previous Training Courses}

The existing evidence on the actual impact of training in ICT skills for teachers is scarce. Law et al.'s (2008) research compared the percentages of teachers who had attended two kinds of professional development activities: ICT and pedagogyrelated. In their findings, the percentages were higher for technical activities than for pedagogical activities (Law et al., 2008). However, a technical course is not enough for teachers to learn how to integrate ICT into their teaching process 
(Meyer and Bo-Kristensen, 2012). A significant deficit in teacher training in the use of ICT and its application in the classroom is also revealed by Fernandez-Cruz and Fernandez-Diaz (2016) who show that teachers' classroom strategies regarding the use of ICT resources as an avenue for complex and collaborative learning have not yet been implemented as teaching methods in the development of Students' digital competence. However, teachers who had a computer and Internet access at home considered ICT as improving the teaching-learning process had a good level of training in ICTs (Ghavifekr et al., 2014; Ghavifekr and Rosdy, 2015). Despite the general shortage of evidence on this topic, it is reasonable to expect that teachers who have previously attended training in online teaching will evaluate their skills more positively than those who have not.

H6: teachers who have previously attended training in online teaching will evaluate their skills more positively than those without such training.

As described above, Romania is not geographically homogenous. Therefore, in addition to the stated hypotheses, going forward we introduce county indicators as controls of probable contextual variation in digital resources.

\section{METHODOLOGY}

\section{Data}

The data used in these analyses were collected through simple random technique from teachers active in pre-tertiary education in Romania through an online survey conducted by the University of Oradea and the University of Suceava. 3,419 valid self-administered online questionnaires were completed between the 1st and 7th of April 2020. From a territorial point of view, the sample is not representative, as the population of teachers from the NE areas of Romania is overrepresented. In the subsequent analyses, we have used a weighted database to assure representativity regarding the proportions of teachers by the educational cycles and the type of locality in which they teach. Weighting was performed using data about the demographics of Romania's teaching staff published by the National Institute of Statistics-Institutul Naţional de Statistică (INS, 2018).

\section{Dependent Variables}

Teachers' perceived digital competences.

Eight Likert-type items of perceived ability were used initially to measure the teachers' self-assessed digital competences.

1. Creating and editing documents in an Office program (e.g., Word or PowerPoint)

2. Creating and editing educational video content

3. Distributing content, tasks, and feedback to students using email

4. Distributing content using messaging applications (e.g., WhatsApp, Facebook, and Messenger)

5. Organizing video conferences using an appropriate platform (e.g., Zoom, WebEx, and Skype)
6. Creating a videoconference using a video streaming solution (e.g., YouTube, Facebook)

7. Distributing content and tasks, as well as delivering feedback through e-learning or distance learning platforms (e.g., Google Classroom, Moodle, and Microsoft Teams)

8. Developing and managing their website to deliver content

Factor analysis of the teachers' responses using principal axis factoring and Varimax rotation $(\mathrm{KMO}=0.869)$ revealed the twodimensional structure of the data, with the first factor covering $53.5 \%$ of the variance in the data and the second showing $16.94 \%$. The most important factor is after rotation loadings larger than 0.5 for the items related to video editing; video streaming; videoconferencing; using e-learning and distance learning platforms, and developing and managing websites (items 2 , and 5-8). The second dimension covers the items concerning the skills for using digital office programs, emails, and chat and messaging applications (items 1,3 , and 4 ). Noticeably, the first factor refers to multimedia and online skills, while the second refers to digital office skills: therefore, we will call them Self-assessed Multimedia and Online Skills Score (SMOS) and Self-Assessed Digital Office Skills Score (SDOS), respectively. To preserve as much information as possible from the data, we have used the factor scores as separate measures of the two constructs instead of using cumulative scores as is often the norm in this type of measurement. For both respective scales, alpha is $>0.7$.

Since both measures of self-perceived digital skills are factor scores, their average is null, and the standard deviation is close to 1. However, both variables have distributions skewed to the right, with longer tails on the negative sides.

Our scale is a self-assessment tool as are the ones developed by the Digital Skills Accelerator of the EU for example (Misheva, 2021), or the digital competences self-assessment tool of DigiCompEdu (Digital Skills Accelerator, n.d.; Redecker and Punie, 2017), another instrument based on the EU's digital competences framework. However, ours is a much shorter and simpler one with items tailored to the immediate technical needs of online teaching at the start of the pandemic and the abrupt and masse entrance in online teaching.

\section{Independent Variables}

All independent variables used in the analysis were dummy coded. This was imposed according to their categorical measurement in the survey, including age which was recorded using intervals. The list of independent variables and their distributions are in Table 1.

\section{Analytic Strategy}

The stated hypotheses were tested using hierarchical linear regressions of the two independent variables separately. To achieve the purpose of identifying interactions and mediation effects, we have grouped the independent variables into eight blocks that were added sequentially to the regression models. Not all dummies covering a dimension were introduced in modeling due to redundancy (the number of dummies included in regression must be mostly $n=1$ of the number of categories of the original categorical variables) and because of collinearities. 
TABLE 1 | Independent variables in hierarchical linear regression.

\begin{tabular}{|c|c|c|c|c|c|c|}
\hline Dimension & $\begin{array}{l}\text { Sub- } \\
\text { dimension }\end{array}$ & Name of variable & Measurement & 0 & 1 & $\%$ yes \\
\hline Gender & Gender & Female01 & Dummy (1 = female) & 590 & 2,805 & 82.6 \\
\hline \multirow[t]{5}{*}{ Age } & Age & Age: yrs31_40 & Dummy & 2,474 & 920 & 27.1 \\
\hline & & Age: under30 & Dummy & 3,149 & 246 & 7.2 \\
\hline & & Age: yrs41_50 & Dummy & 2,020 & 1,375 & 40.5 \\
\hline & & Age: yrs51_60 & Dummy & 2,670 & 724 & 21.3 \\
\hline & & Age: over60 & Dummy & 3,265 & 129 & 3.8 \\
\hline \multirow[t]{9}{*}{ Context of school } & Place of school & Place: urban_school & Dummy & 1,299 & 2,096 & 61.7 \\
\hline & $\begin{array}{l}\text { Domicile of } \\
\text { teacher }\end{array}$ & Domicile: same place with school & Dummy & 1,325 & 2,069 & 61.0 \\
\hline & County & County: Arad & Dummy & 3,274 & 121 & 3.6 \\
\hline & & County: Bihor & Dummy & 3,100 & 295 & 8.7 \\
\hline & & County: Botoşani & Dummy & 2,712 & 683 & 20.1 \\
\hline & & County: Covasna & Dummy & 3,237 & 158 & 4.7 \\
\hline & & County: Maramureş & Dummy & 3,197 & 198 & 5.8 \\
\hline & & County: Neamţ & Dummy & 2,289 & 1,105 & 32.6 \\
\hline & & County: Suceava & Dummy & 2,841 & 554 & 16.3 \\
\hline \multirow[t]{3}{*}{ Status in the profession } & $\begin{array}{l}\text { Employment } \\
\text { status }\end{array}$ & Employment status: replacement & Dummy & 2,985 & 409 & 12.1 \\
\hline & & Employment status: tenure & Dummy & 478 & 2,916 & 85.9 \\
\hline & & Employment status: tenure_temporary & Dummy & 3,325 & 69 & 2.0 \\
\hline \multirow[t]{7}{*}{ Status in the profession } & Type of school & Type of school: HS_college_nat & Dummy & 3,131 & 263 & 7.7 \\
\hline & & Type of school: HS_college_tech & Dummy & 3,128 & 266 & 7.8 \\
\hline & & Type of school: HS_lic_technological & Dummy & 2,987 & 407 & 12,0 \\
\hline & & Type of school: HS_lic_theor & Dummy & 3,198 & 196 & 5.8 \\
\hline & & Type of school: HS_lic_vocational & Dummy & 3,194 & 201 & 5.9 \\
\hline & & Type of school: Lower_secondary_school & Dummy & 1,491 & 1,904 & 56.1 \\
\hline & & Type of school: Primary_school & Dummy & 3,237 & 157 & 4.6 \\
\hline \multirow[t]{4}{*}{ Status in the profession } & $\begin{array}{l}\text { Teacher's } \\
\text { degree }\end{array}$ & Degree: definitive & Dummy & 2,893 & 502 & 14.8 \\
\hline & & Degree: doctor & Dummy & 3,297 & 98 & 2.9 \\
\hline & & Degree: degree_grade1 & Dummy & 1,216 & 2,178 & 64.2 \\
\hline & & Degree: degree_grade2 & Dummy & 2,919 & 475 & 14.0 \\
\hline \multirow[t]{4}{*}{ Field } & Field & $\begin{array}{l}\text { Field: Humanities languages, history, } \\
\text { religion, arts }\end{array}$ & Dummy & 2,152 & 1,242 & 36.6 \\
\hline & & $\begin{array}{l}\text { Field: sciences_ch_ph_bio Chemistry, } \\
\text { physics, biology }\end{array}$ & Dummy & 3,064 & 330 & 9.7 \\
\hline & & Field: Mathematics & Dummy & 3,076 & 318 & 9.4 \\
\hline & & Field: ITC_informatics & Dummy & 3,234 & 161 & 4.7 \\
\hline $\begin{array}{l}\text { Attended digital } \\
\text { teaching courses }\end{array}$ & $\begin{array}{l}\text { Attended digital } \\
\text { teaching } \\
\text { courses }\end{array}$ & Attended digital teaching courses & Dummy & 2,968 & 426 & 12.6 \\
\hline
\end{tabular}

Furthermore, given the almost orthogonal relationship between the two dependent variables (correlation), it is likely that their sources of variation are somewhat different (see Table 2).

\section{RESULTS}

\section{Hierarchical Linear Regressions: Model Fit Change}

The final explanatory power of the regressions for both dependent variables slightly exceeds $7.5 \%$ of the total variances, with a positive value for SDOS, where $8.2 \%$ of the variance is covered by the 29 dummy variables included in the final model (Table 3). Such a low explanatory power is due to the large size of the sample, the absence of some important predictors from the specifications of the models, e.g., home ICT resources and ICT experience at home and outside of school, and the penalty incurred by many predictors when computing adjusted $R^{2}$.

Our specifications more effectively cover the variation of the Self-Assessed Digital Office Skills Score (SDOS) than the SelfAssessed Multimedia and Online Skills Score (SMOS).

While variables indicating teachers', professional certificates do not contribute at all to the variance of the dependent variables, as three other blocks have a significant impact only on SDOS, 
TABLE 2 | The sequence of variables included in hierarchical linear modeling.

\begin{tabular}{ll}
\hline Block & Dimensions, variables \\
\hline 1 & Gender, Age (under 30, 31-40, \\
& $41-50$, over 60) \\
& Place of school (urban vs. rural), \\
& Domicile of teacher (same place \\
& with school) \\
& County (Arad, Bihor, Botoşani, \\
& Covasna, Maramures, Neamt, \\
& Suceava) \\
& Employment status (replacement or \\
& temporary tenure) \\
& Type of school (National college, \\
5 & Technical college, Technological \\
& lyceum, Lower secondary school, \\
& Primary school) \\
& Teacher's degree (definitive, \\
& doctor- phd, grade 2) \\
& Field (humanities, sciences, \\
& mathematics, IT) \\
& Attended digital teaching courses \\
\hline
\end{tabular}

i.e., location of school; the domicile of teacher compared with the location of school and employment status of teacher and type of school employing a teacher. The variables in the remaining three blocks have significant parameters: gender and age, the field in which the teacher is teaching, and whether online teaching courses were attended.

\section{Models Compared}

The detailed tables of the parameters of hierarchical regressions reveal interesting differences between the two scores of selfperceived skills as much as suggesting the impact of status in the profession on SDOS (Table 4).

Stepwise comparisons of the parameters in the block models do not reveal significant interactions and mediation effects with salient suppression effect of status in the profession on the impact of age. The most salient difference between the models for the two dependent variables is the contrast found regarding teachers' genders. Female teachers reported perceiving their multimedia and online digital skills at a lower level than their male counterparts. As such, it seems that female teachers view themselves as specializing in solving digital office tasks more than male teachers, while male teachers view themselves to be more skilled in the creative roles of devising and distributing online and multimedia content.

In terms of the relationship between the teachers' ages and their self-assessed digital competences, for both dependent variables, belonging to the oldest age group correlates with a lower reported competence level in contrast with the younger ones. However, there are some differences between the two dependent variables: while age group parameters remain almost unchanged across models for SMOS, they increase in the case of SDOS with every group of variables added. This suggests that where the variation of Self-Perceived Digital Office Skills is concerned, the impact of age is suppressed by other variables, especially by those in the second block (i.e., location of work and domicile), those in the fourth block (i.e., employment status), and teachers' degrees. In simple terms, this suppression is since positions that indicate higher status in the education field (e.g., tenure, grade, or being a teacher in urban areas) suppose better digital office skills, but simultaneously are negatively related to age. Controlling for status in the education field makes the impact of age on digital office skills more evident. The impact of age group on SDOS is the largest out of all the regressions if the size of betas is considered.

Regarding the relationship between the geographical location of schools and teachers' self-assessed digital competences, teachers working in urban schools report having higher SMOS and SDOS than their rural counterparts, with the parameters being larger in the case of digital office skills. On the other hand, both the teacher being a resident in the same place as the school where they teach or having to commute are non-consequential in terms of their influence on the dependent variable.

With the notable exception of Suceava, counties in which the teachers teach generally do not have significant parameters on either dependent variable. Teachers residing in counties in NE Romania, mainly Suceava, and with smaller parameters in Botoşani and Neamţ, appear to have a lower self-assessment of their digital, online, and multimedia skills.

Regarding the influence of professional status on selfassessed digital competences, the blocks that included variables designating the status of subjects in the profession (i.e., employment status and type of school) have a significant

TABLE 3 | Model fit change in hierarchical linear modeling.

\begin{tabular}{|c|c|c|c|c|c|c|}
\hline \multirow[b]{2}{*}{ Model } & \multicolumn{3}{|c|}{ SMOS } & \multicolumn{3}{|c|}{ SDOS } \\
\hline & Adjusted R square & df1 & Sig. F change & Adjusted R square & df1 & Sig. F change \\
\hline 1 & 0.030 & 5 & 0.000 & 0.028 & 5 & 0.000 \\
\hline 2 & 0.031 & 2 & 0.079 & 0.052 & 2 & 0.000 \\
\hline 3 & 0.040 & 7 & 0.000 & 0.055 & 7 & 0.014 \\
\hline 4 & 0.040 & 2 & 0.083 & 0.057 & 2 & 0.003 \\
\hline 5 & 0.041 & 5 & 0.270 & 0.062 & 5 & 0.001 \\
\hline 6 & 0.041 & 3 & 0.191 & 0.062 & 3 & 0.106 \\
\hline 7 & 0.059 & 4 & 0.000 & 0.074 & 4 & 0.000 \\
\hline 8 & 0.076 & 1 & 0.000 & 0.082 & 1 & 0.000 \\
\hline
\end{tabular}


TABLE 4 | The models compared.

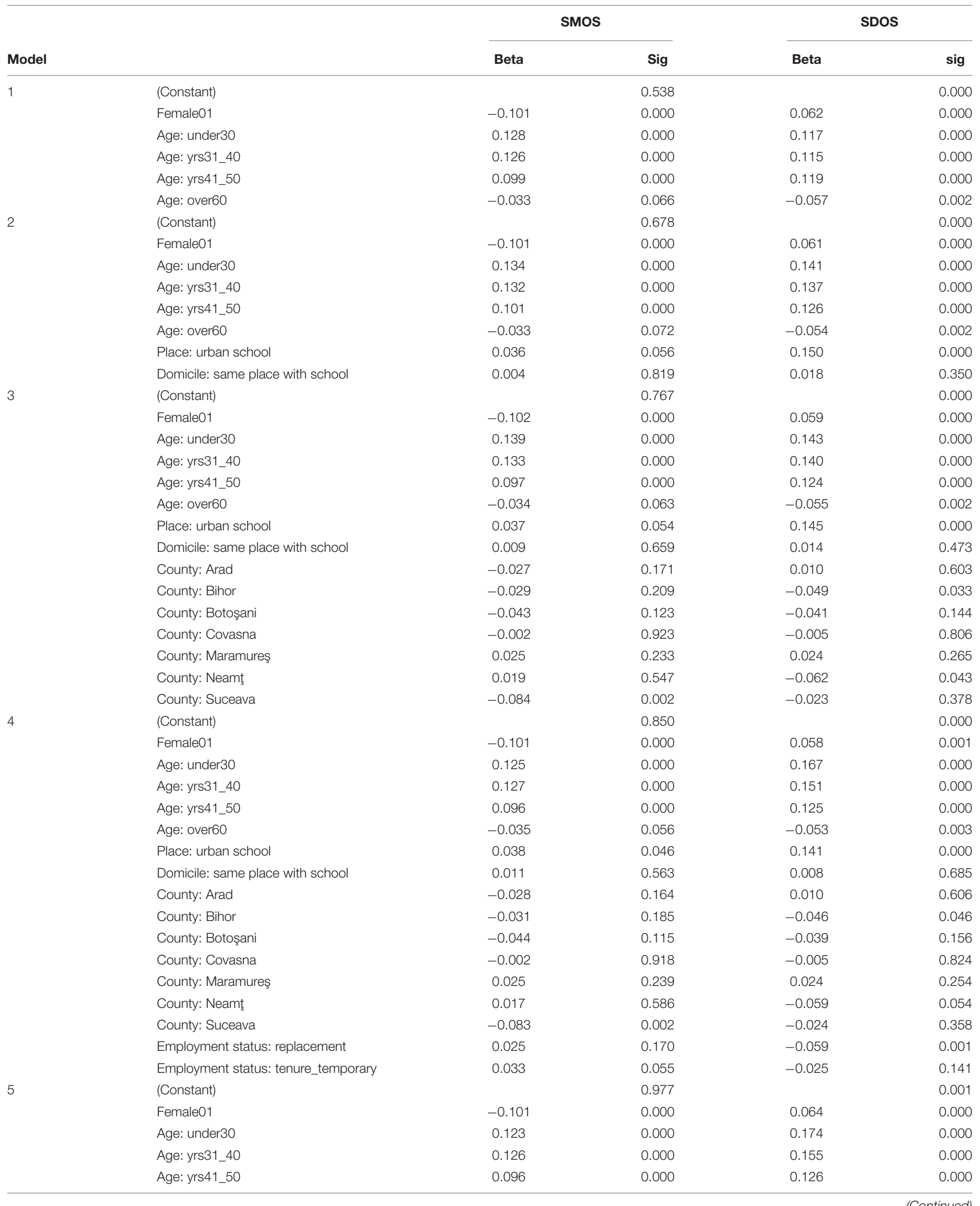


TABLE 4 | (Continued)

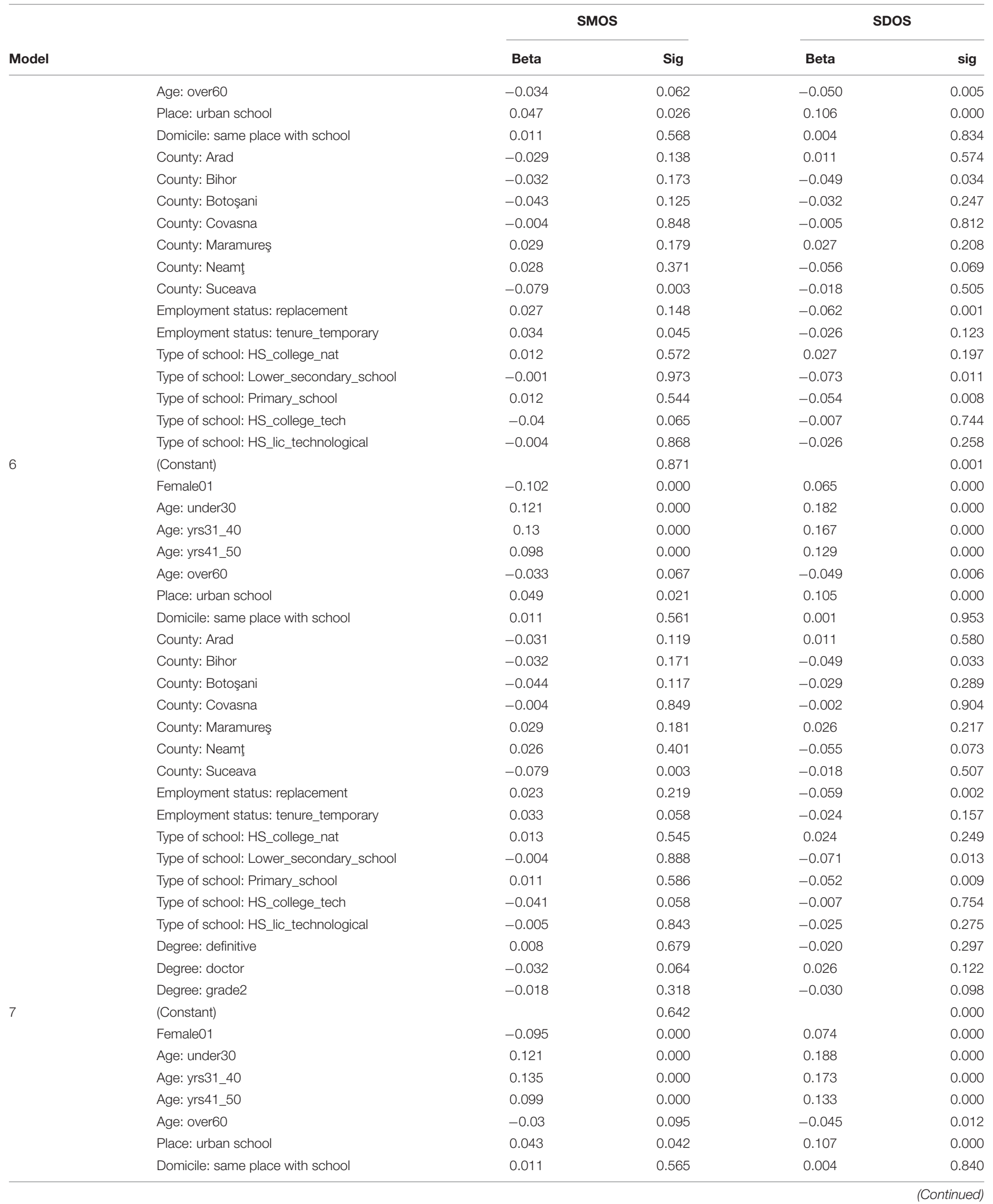


TABLE 4 | (Continued)

\begin{tabular}{|c|c|c|c|c|c|}
\hline \multirow[b]{2}{*}{ Model } & & \multicolumn{2}{|c|}{ SMOS } & \multicolumn{2}{|c|}{ SDOS } \\
\hline & & Beta & Sig & Beta & sig \\
\hline & County: Arad & -0.033 & 0.098 & 0.017 & 0.379 \\
\hline & County: Bihor & -0.032 & 0.170 & -0.044 & 0.056 \\
\hline & County: Botoşani & -0.044 & 0.118 & -0.028 & 0.305 \\
\hline & County: Covasna & -0.002 & 0.937 & -0.001 & 0.979 \\
\hline & County: Maramureş & 0.023 & 0.288 & 0.018 & 0.384 \\
\hline & County: Neamţ & 0.029 & 0.349 & -0.050 & 0.105 \\
\hline & County: Suceava & -0.081 & 0.002 & -0.021 & 0.419 \\
\hline & Employment status: replacement & 0.02 & 0.281 & -0.067 & 0.000 \\
\hline & Employment status: tenure_temporary & 0.03 & 0.083 & -0.023 & 0.184 \\
\hline & Type of school: HS_college_nat & 0.013 & 0.534 & 0.019 & 0.355 \\
\hline & Type of school: Lower_secondary_school & -0.002 & 0.953 & -0.065 & 0.022 \\
\hline & Type of school: Primary_school & 0.002 & 0.928 & -0.038 & 0.064 \\
\hline & Type of school: HS_college_tech & -0.038 & 0.074 & -0.001 & 0.960 \\
\hline & Type of school: HS_lic_technological & -0.007 & 0.767 & -0.024 & 0.285 \\
\hline & Degree: definitive & 0.007 & 0.739 & -0.023 & 0.230 \\
\hline & Degree: doctor & -0.023 & 0.184 & 0.026 & 0.117 \\
\hline & Degree: grade2 & -0.018 & 0.304 & -0.032 & 0.076 \\
\hline & Field: Humanities Languages, history, religion, arts & -0.052 & 0.005 & 0.038 & 0.039 \\
\hline & Field: sciences_ch_ph_bio Chemistry, physics, biology & -0.058 & 0.001 & 0.018 & 0.311 \\
\hline & Field: Mathematics & -0.038 & 0.027 & 0.023 & 0.174 \\
\hline & Field: ITC_informatics & 0.118 & 0.000 & 0.112 & 0.000 \\
\hline \multirow[t]{30}{*}{8} & (Constant) & & 0.988 & & 0.000 \\
\hline & Female01 & -0.097 & 0.000 & 0.072 & 0.000 \\
\hline & Age: under30 & 0.124 & 0.000 & 0.190 & 0.000 \\
\hline & Age: yrs31_40 & 0.138 & 0.000 & 0.175 & 0.000 \\
\hline & Age: yrs41_50 & 0.102 & 0.000 & 0.134 & 0.000 \\
\hline & Age: over60 & -0.026 & 0.141 & -0.042 & 0.017 \\
\hline & Place: urban school & 0.04 & 0.055 & 0.105 & 0.000 \\
\hline & Domicile: same place with school & 0.01 & 0.594 & 0.003 & 0.865 \\
\hline & County: Arad & -0.031 & 0.114 & 0.018 & 0.346 \\
\hline & County: Bihor & -0.029 & 0.213 & -0.042 & 0.067 \\
\hline & County: Botoşani & -0.045 & 0.100 & -0.030 & 0.283 \\
\hline & County: Covasna & 0 & 0.998 & 0.000 & 0.980 \\
\hline & County: Maramureş & 0.018 & 0.386 & 0.015 & 0.461 \\
\hline & County: Neamţ & 0.031 & 0.308 & -0.048 & 0.114 \\
\hline & County: Suceava & -0.086 & 0.001 & -0.024 & 0.350 \\
\hline & Employment status: replacement & 0.026 & 0.164 & -0.063 & 0.001 \\
\hline & Employment status: tenure_temporary & 0.029 & 0.084 & -0.023 & 0.177 \\
\hline & Type of school: HS_college_nat & 0.009 & 0.663 & 0.017 & 0.424 \\
\hline & Type of school: Lower_secondary_school & 0 & 0.991 & -0.064 & 0.024 \\
\hline & Type of school: Primary_school & 0.003 & 0.902 & -0.037 & 0.066 \\
\hline & Type of school: HS_college_tech & -0.038 & 0.076 & -0.001 & 0.975 \\
\hline & Type of school: HS_lic_technological & -0.003 & 0.899 & -0.022 & 0.338 \\
\hline & Degree: definitive & 0.005 & 0.780 & -0.024 & 0.214 \\
\hline & Degree: doctor & -0.025 & 0.144 & 0.025 & 0.136 \\
\hline & Degree: grade2 & -0.015 & 0.393 & -0.029 & 0.097 \\
\hline & Field: Humanities Languages, history, religion, arts & -0.052 & 0.005 & 0.038 & 0.041 \\
\hline & Field: sciences_ch_ph_bio Chemistry, physics, biology & -0.057 & 0.001 & 0.018 & 0.290 \\
\hline & Field: Mathematics & -0.039 & 0.024 & 0.023 & 0.180 \\
\hline & Field: ITC_informatics & 0.110 & 0.000 & 0.107 & 0.000 \\
\hline & Attended digital teaching courses & 0.130 & 0.000 & 0.086 & 0.000 \\
\hline
\end{tabular}


positive impact (i.e., the higher the status, the larger the dependent measure) in the case of self-assessed digital office skills. Conversely, replacement teachers and those in lower secondary schools (i.e., gymnasiums) evaluate their digital office skills especially poorly.

Excluding the impact of age, the (positive) effects of being an ICT teacher and of having attended a distant education training, respectively, are the strongest for both dependent variables. It is interesting to note here that SMOS is significantly smaller for teachers of all other topics included in the modeling, which is not the case for SDOS.

\section{DISCUSSION}

Multivariate modeling of the two measures of selfperceived digital skills produced some rather straightforward results, although the interpretation of these results is not necessarily undoubtful.

\section{Self-Assessed Digital Skills and Age Relationship}

In the findings of the present study, age plays an expected role in teachers' perception of their digital skills. Socialized and accustomed to digital devices, systems, and environments, younger teachers have more confidence in their ICT skills regardless of other characteristics. These results are like those of Fernandez-Cruz and Fernandez-Diaz (2016), who also found that self-assessed digital skills are negatively correlated with age for teachers.

However, the most interesting results are those that relate SMOS and SDOS with gender, age, and status in the profession, thus revealing some of the internal dynamics of the teaching profession and its relationship with digital skills.

\section{Self-Assessed Digital Skills and Gender Relationship}

The contrasting parameters of gender in the present study reveal the gendered nature of tasks in the teaching profession, or at least the perceived gender stereotypes concerning these abilities: multimedia and online skills are self-reported as a specialty of male teachers, while digital office skills are selfreported as a specialty of female teachers. Indeed, it is possible to speculate more broadly here around the gendered nature of work roles and workplace hierarchies, or indeed about the recent history of women being forced into clerical or secretarial roles (Alshabani et al., 2020; Balka and Wagner, 2020). However, several studies show that there is no significant effect of gender on actual digital skills, and instead, differences in skill sets are more likely to relate to social, historical, cultural, or other contextual differences between male and female teachers (Law et al., 2008). The difference of perceived digital skills in favor of male teachers in the present study may also be caused by narcissistic aspects of their personality (Philipson, 1985), leading them to self-assess their ICT skills more highly than their actual ICT skills.

\section{Self-Assessed Digital Skills and School Location Relationship}

Teachers in urban schools have higher perceived digital skills, with the parameters being larger in the case of digital office skills. Teachers being resident in the same place as the school where they teach or having to commute are both non-consequential upon the dependent variable. Indeed, this result is similar to Koen et al. (2017); however, taking into consideration the socioeconomic status of the areas in which the schools are located as well, it is perhaps almost self-evident that the urban school teachers will have greater perceived digital skills, given that urban areas are recipient to greater investment, infrastructure, and training opportunities (Wiesel and Liu, 2020). Eroğlu and Şenol (2021) made phenomenological research about emergency remote education experiences of teachers during the COVID-19 Pandemic with students being mostly in the low socioeconomic group. Their results show that emergency remote education was ineffective due to low student participation, insufficient infrastructure, lack of responsibility and motivation for learning, low ICT competency of students and teachers, low socioeconomic status, and inappropriateness of planning and curriculums.

\section{Self-Assessed Digital Skills and Professional Status Relationship}

The parameters revealing the fact that teachers occupying peripheral positions in the teaching professions are equally intriguing (i.e., replacement teachers and those teaching in lowersecondary schools or primary schools) as lower self-assessed office digital skills than those with positions was demonstrated as more important; on the other hand, the same trend does not exist in the case of multimedia and online skills. Evidently, ascension in the professional hierarchy can be partially facilitated by having digital office skills, and the reverse causation could also be possible; however, this is a self-perpetuating truth as the higher the standing of the teacher, the more they have the opportunity to practice digital skills for certain tasks, on the principle of the Matthew effect: "the one who has it will be given to him" (Mingo and Bracciale, 2018). Furthermore, researchers suggest that higher qualifications lead to teachers developing and having higher levels of actual digital skills, and this might be the consequence of the combination of proper knowledge, skills, and attitudes that increase the innovative use of ICT (Gudmundsdottir and Hatlevik, 2018; West et al., 2019).

\section{Self-Assessed Digital Skills and School Subject Relationship}

In the present study, it was also expected that specialization in IT, i.e., as a teacher of ITC and informatics-would significantly predict higher SDOS and SMOS. However, the fact that other subject fields appear to have a negative impact on SMOS, or no effect at all in the case of SDOS, is perhaps less intuitive.

The present study results suggest that any correlation that might be perceived between the subject field and self-assessed digital skills would be erroneous, produced by confounding factors. In this case, gender and status in the field are evident 


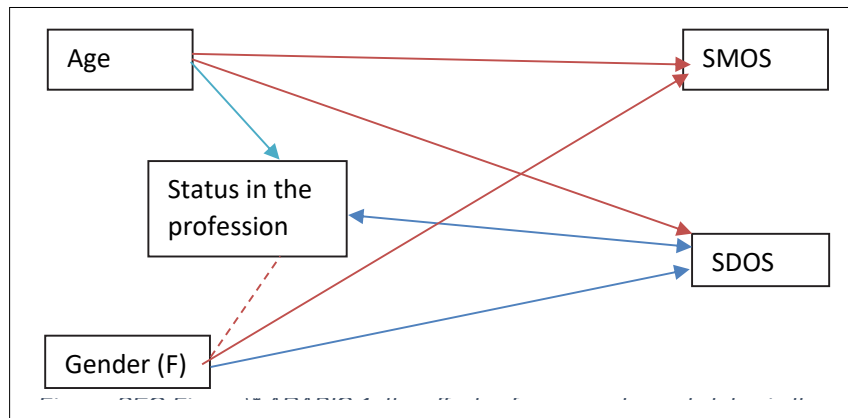

FIGURE 2 | Correlation between factors.

variables whose impact could be confounded with that of the subject field (see Figure 2).

The impact of the technology field is confirmed in other studies as well (Fernandez-Cruz and Fernandez-Diaz, 2016), but an interesting avenue for further research would be to ascertain whether teachers with a high level of self-assessed digital skills report themselves to do better than other teachers at other activities as well (e.g., pedagogical skills).

\section{Self-Assessed Digital Skills and Professional Training Relationship}

In the present study's results, prior participation in distance teaching training is positively related to the dependent variables which could be understood, on an immediate level, as a simple indicator of the impact of that training. However, on the one hand, this correlation could be partly fallacious, explained instead by teachers' interest in online teaching, and on the one hand, causality could also be inferred from self-perceived skills to participate in distance education training sessions. There are no relevant results to compare with the present study. Law et al. (2008) only draw attention to the difference between online skills in training courses, by promoting technical and pedagogical skills in an online environment.

Considering the reverse sign effects involving these predictors, regarding the two dependent variables, though statistically not significant, it could be hypothesized that here, as in the case of the effect of gender, there are two contrasting causal mechanisms. Based on the results of the present study, it can be inferred that having multimedia and online skills is not yet a correlate of a successful career in the teaching profession. Further investigations are required, however, to clarify what the actual relation of advancement in career is for teachers with certain digital skills, along with whether or not these relationships are connected with structural variables like age, length of career, and gender, as might seem plausible given the current study results.

\section{Educational Implications}

This critical period, a global pandemic, has been a wake-up call, with schools closed and lessons suddenly transferred online (Lim, 2020). Few teachers were readily able to do this (Edelhauser and Lupu-Dima, 2020), hence their (ongoing) need to attend courses to enhance their skills and abilities in using technology in their professional practice. On the other hand, going forward, schools should consider this need more seriously and invest the necessary funds for equipping laboratories and classrooms with computers, as well as in-service teacher training courses regarding digital tools for education. There is still a significant problem with teacher training in terms of efficiently using technology for various reasons: some teachers either do not want to learn how to use it, the training courses are not effective, or put simply, some of them fundamentally do not agree with using ICT (Holotescu et al., 2020). Indeed, Gudmundsdottir and Hatlevik (2018) highlight recent research that indicates a discrepancy between digital requirements and teachers' training in technology use. Many teachers perceive themselves to have a low level of computer competence (Santi et al., 2020), thus they develop a neutral attitude toward ICT or they only use technology when it is necessary (Sundqvist et al., 2020), as they may be anxious and unconfident in their use of technology (Klapproth et al., 2020). In this case, teachers can be understood as "digital immigrants" in that they only learn about ICT tools, but do not necessarily immerse or live with a positive attitude about new technologies (Kesharwani, 2020; Anzari et al., 2021; Noronha-Sousa et al., 2022). Education cannot ignore the rapid and far-reaching development of technology and its applications. In practice, this presents a real challenge because ICT is involved across the entire education system: from organizational change (e.g., time and place for independent or collaborative learning, tailored instruction, etc.), to means of delivering educational content (Heitink et al., 2016).

At present, there is a need for comprehensive and up-todate education policies regarding digital competences, both for educational management (Karakose et al., 2021b) and for teacher training (OECD, 2019e). In terms of pre-service teacher training, it is important for universities to provide quality training and to adapt all courses to address new technologies and trends (Engen and Engen, 2019). As such, it is crucial to have highly qualified university teachers who are developing new methods and tools for teaching and learning. Post-pandemic, modern pedagogy must be fundamentally revised, including elements of e-learning (Paniagua and Istance, 2018): namely regarding the use of digital tools in education and promoting in-service training for teachers (Napal-Fraile et al., 2018).

On an education management level, there are several priorities: adapting all learning processes to fit with new technology, analyzing available resources (i.e., both human and technological), developing ways of communicating via the internet (e.g., Facebook, WhatsApp, and multimedia tools), and keeping abreast of new and emerging pedagogical trends for digital teaching and learning (Shonfeld et al., 2020). There is cause for hope, as, in recent years, literature has highlighted that teachers are increasingly becoming followers of technology when they have access to comprehensive infrastructure, ICT devices in schools, training, and support in their school environments and communities (Hatos, 2019). A study about teachers' perspective on school development at German vocational schools during the COVID-19 pandemic shows that the main coping strategies proved to be a clear agenda by the school leadership in connection with reliable technological infrastructure and 
teachers' willingness to use digital teaching methods and König et al. (2020) and Delcker and Ifenthaler (2021) in his study about adapting to online teaching during COVID-19 school closure in the same country, show that information and communication technologies (ICT) tools, particularly digital teacher competence and teacher education opportunities to learn digital competence, are instrumental in adapting to online teaching during COVID19 school closures. The Ministry of Education can even adopt system and technology innovations that will expand the use of distance learning and distance or alternative assessments (OECD, 2020c).

Ultimately, technology, and teachers' effective use of it ( $\mathrm{Al}$ Kodri, 2021), is an invaluable means of creating a learning and working environment for twenty-first-century students (especially during the online schooling period during the COVID-19 pandemic), helping them develop co-operation skills, communication abilities, problem-solving skills, and capacity for continuous learning (Huda et al., 2018), providing teachers with the necessary training and framework for technologyrelated professional development (Choi et al., 2021), and as Christopoulos and Sprangers (2021) say: simultaneously careful examining the characteristics of proposed platforms or tools and a trial of such characteristics before integration within an educational system.

\section{Ethical Considerations}

Core principles of ethical considerations, for which there was complete agreement across the authors, were consistently adhered to across all participating institutions. The participants gave their free, informed consent, were aware of their right to withdraw from the study, and understood that all data would be anonymized. The participants were all teachers, and they are highly educated adults able to fully understand these concepts and, as such, this was deemed to be a low-risk study by all institutions.

\section{Limits of the Present Research}

The present research faced several limits in achieving its objectives. Firstly, there is a distinct possibility of bias in the sample as it was self-selected using an online questionnaire. Selfselection of the sample, as well as the self-reported technique used, might have correlated with the dependent variables, thus potentially distorting the results.

Another significant issue with the present research is the absence of a measure of actual digital skills. Therefore, it cannot be assessed how much these real skills reflect the teachers' perception of their digital skills. This translates into another limitation: the underspecified value of the multiple regressions. It is plausible to assume that a large part of the significant unexplained variance is covered by the impact of actual skills, which should have been measured using observational indicators.

\section{CONCLUSION}

The present research analyzed the perceived digital skills of Romanian pre-tertiary cycle teachers concerning their professional status, the context of the school in which they teach, their gender, their age, their taught field, and their previous participation (or lack of) in training for online teaching. Using data from 3,419 questionnaires in an online survey selfcompleted by these teachers at the beginning of the COVID19 lockdown (i.e., the first half of April 2020), two consistent measures of perceived digital skills have been built as factor scores from 8 items, yielding Self-assessed Multimedia and Online Skills Scores (SMOS) and Self-Assessed Digital Office Skills Scores (SDOS), i.e., the dependent variables in this study. Based on current literature on the predictors of digital skills, several hypotheses were built concerning the variations of the two measures of the perceived digital abilities of teachers in the primary and secondary cycles (tested using hierarchical linear regressions).

This study's first conclusion derives from the low explanatory powers of the regressions with full specifications (adjusted $R^{2}$ of 0.076 and 0.082 , respectively), which suggests that the single most important predictor of perceived digital skills are actual digital skills, whose measure is absent from the model.

Most of the hypotheses are positive:

- Younger teachers have more confidence in their ICT skills regardless of any other characteristics (H1).

- Teachers in urban schools have higher self-perceived digital skills (H3).

- teachers, who are active primarily in STEM fields, particularly in computing and informatics, evaluate their ICT skills more positively than other teachers (in other subject fields) (H5).

- Prior participation in training for distance teaching is positively related to this study's dependent variables (H6).

However, exceptions persist, especially concerning $\mathrm{H} 2$ and $\mathrm{H} 4$ :

- Self-perceived multimedia and online skills are selfreported as a specialty of male teachers, while selfperceived digital office skills are self-reported as a specialty of female teachers. It is unclear if this notable contrast mirrors actual skills or is a by-product of gendered stereotypes impacting self-assessment.

- Teachers with peripheral positions in the teaching profession (i.e., replacement teachers and those teaching in lower-secondary schools or primary schools) have lower self-assessed office digital skills than those with positions seen to be more important. However, the same is not true in the case of multimedia and online skills. There is also a suppression involving age and position in the profession: positions that indicate a higher status in the education field (i.e., tenure, grade, or being taught in an urban area) suppose better digital office skills; however, simultaneously, they are negatively related to age, therefore controlling for status in the education field makes the impact of age on digital office skills more evident.

Considering all these conclusions to the present study, it is clear that post-pandemic Romania's pedagogical paradigms must be rethought. Teachers must be aware that digital competences 
will be integrated into professional competences, and they must proactively act and reflect on their development of this critical skill set. For education managers and local authorities, it is a priority to ensure a high-quality education through providing the material resources (i.e., computers, internet connection, and devices for all children and teachers) and sustaining the in-service courses for teachers and staff about the possibilities of adapting to this contemporary challenge (Simuţ et al., 2021). For education policy-makers, it is necessary to analyze all available information and make forward-thinking decisions regarding both national and European strategies about European key competences; teachers' digital competences; and digital education strategy, monitoring, and implementation (Commission/Eurydice, 2019).

For teachers, using ICT in their professional practice can be considered an efficient and effective means of facilitating access, storage, transmission, and manipulation of different information sources and content via audio and video due to its capacity to establish a proactive teaching and learning environment. The education community is currently fundamentally affected by the impact of a new, pressing need for communication and information technologies that are more and more integrated into pedagogical practices and methods, allowing for the consideration of new directions, improvements, or even transformations (Ali, 2020). Indeed, ICT in education can be used for a wide range of different purposes, such as active teaching and learning through Students' involvement

\section{REFERENCES}

Akmal, A., Fikri, A., Rahmawati, T., Hendri, Z., and Sari, N. (2021). Measuring online learning readiness during coronavirus pandemic: an evaluative survey on history teachers and students. J. Pajar (Pendidikan dan Pengajaran) 5, 98-110. doi: 10.33578/pjr.v1i1.8169

Aktag, I. (2015). Computer self-efficacy, computer anxiety, performance and personal outcomes of turkish physical education teachers. Educ. Res. Rev. 10, 328-337. doi: 10.5897/ERR2014.2016

Al Darayseh, A. (2020). The impact of COVID-19 pandemic on modes of teaching science in UAE schools. J. Educ. Pract. 11:110.

Al Kodri, M. (2021). The role of digital technology in sustaining online learning during the pandemic Covid19. Uicell Confer. Proc. 4, 24-31.

Ali, A. (2020). Conception d'un dispositif hypermédiatique pour développer quelques compétences de la production écrite en FLE. J. Educ. 68, 1-35.

Ali, W., and Kaur, M. (2020). Educational challenges amidst covid-19. Pandemic 6, 40-57.

Alshabani, N., Gonzalez Lopez, A., Graham, E. L., and Soto, S. (2020). A historical analysis of the vocational guidance of women. Psychol. From Margins 2:1.

Anzari, P. P., Shiddiq, A., Huda, I., Pratiwi, S. S., Fatanti, M. N., and Silvallana, D. F. V. (2021). Teachers' technological capability as digital immigrants in learning from home activities. Int. J. Emerg. Technol. Learn. 16, 146-159. doi: 10.3991/ijet.v16i07.21229

Arkorful, V., Barfi, K. A., and Aboagye, I. K. (2021). Integration of information and communication technology in teaching: initial perspectives of senior high school teachers in Ghana. Educ. Inform. Technol. 26, 1-17. doi: 10.1007/ s10639-020-10426-7

Asad, M. M., Hussain, N., Wadho, M., Khand, Z. H., and Churi, P. P. (2020). Integration of e-learning technologies for interactive teaching and learning process: an empirical study on higher education institutes of pakistan. J. Appl. Res. Higher Educ. [Epub ahead of print]. doi: 10.1108/JARHE-04-2020-0103

Awofala, A. O., Akinoso, S. O., and Fatade, A. O. (2017). Attitudes towards computer and computer self-efficacy as predictors of preservice mathematics
(Ghavifekr and Quan, 2020), or helping in lesson planning or the daily life of teachers (Yevelson-Shorsher and Bronstein, 2018). Ultimately, it is necessary to develop technological resources, especially digital tools for education, and to prepare both students and teachers to be digitally adapted by utilizing ICT with efficiency and respect for ethical principles.

\section{DATA AVAILABILITY STATEMENT}

The original contributions presented in the study are included in the article/supplementary material, further inquiries can be directed to the corresponding author/s.

\section{ETHICS STATEMENT}

The studies involving human participants were reviewed and approved by the Stefan cel Mare University. The patients/participants provided their written informed consent to participate in this study.

\section{AUTHOR CONTRIBUTIONS}

All authors listed have made a substantial, direct, and intellectual contribution to the work, and approved it for publication.

teachers' computer anxiety. Acta Didactica Napocensia 10, 91-108. doi: 10. 24193/adn.10.3.9

Awofala, A. O., Olabiyi, O. S., Awofala, A. A., Arigbabu, A. A., Fatade, A. O., and Udeani, U. N. (2019). Attitudes toward computer, computer anxiety, and gender as determinants of pre-service science, technology, and mathematics teachers' computer self-efficacy. Digital Educ. Rev. 36, 51-67. doi: 10.1344/der. 2019.36.51-67

Bacter, C., Bălțătescu, S., Marc, C., Săveanu, S., and Buhaş, R. (2021). Correlates of preadolescent emotional health in 18 countries. a study using children's words data. Child Indic. Res. 14, 1-20. doi: 10.1007/s12187-021-09819-y

Balka, E., and Wagner, I. (2020). A historical view of studies of women's work. Comput. Supp. Cooperat. Work 30, 1-55.

Bandura, A. (1994). Self-efficacy. Encycl. Hum. Behav. 4, 71-81.

Birgin, O., Uzun, K., and Akar, S. G. M. (2020). Investigation of turkish mathematics teachers' proficiency perceptions in using information and communication technologies in teaching. Educ. Inform. Technol. 25, 487-507. doi: 10.1007/s10639-019-09977-1

Brickman, P. (2021). "Expectations and what people learn from failure," in Expectations and Actions: Expectancy-Value Models in Psychology, ed. N. T. Feather, 207-237. doi: 10.4324/9781003150879-10

Buabeng-Andoh, C. (2019). Factors that influence teachers' pedagogical use of ICT in secondary schools: a case of ghana. Contem. Educ. Technol. 10, 272-288. doi: $10.30935 /$ cet.590099

Cabero-Almenara, J., Romero-Tena, R., and Palacios-Rodríguez, A. (2020). Evaluation of teacher digital competence frameworks through expert judgement: the use of the expert competence coefficient. J. New Approaches Educ. Res. 9, 275-293. doi: 10.7821/naer.2020.7.578

Celik, V., and Yesilyurt, E. (2013). Attitudes to technology, perceived computer self-efficacy, and computer anxiety as predictors of computer-supported education. Comput. Educ. 60, 148-158. doi: 10.1016/j.compedu.2012. 06.008

Černochová, M., Voňková, H., Štípek, J., and Černá, P. (2020). “How do learners perceive and evaluate their digital skills?", in Learning and Performance 
Assessment: Concepts, Methodologies, Tools, and Applications. (IGI Global), 1453-1464. doi: 10.4018/978-1-7998-0420-8.ch067

Chang, S. E. (2005). Computer anxiety and perception of task complexity in learning programming-related skills. Comput. Hum. Behav. 21, 713-728. doi: 10.1016/j.chb.2004.02.021

Choi, H., Chung, S.-Y., and Ko, J. (2021). Rethinking teacher education policy in ICT: lessons from emergency remote teaching (ERT) the during COVID-19 pandemic period in korea. Sustainability 13:5480. doi: 10.3390/su13105480

Christopoulos, A., and Sprangers, P. (2021). Integration of educational technology during the Covid-19 pandemic: an analysis of teacher and student receptions. Cogent Educ. 8:1964690. doi: 10.1080/2331186X.2021.1964690

Commission/Eurydice, E. (2019). Digital Education at School in Europe. Eurydice Report. Available online at: https://ec.europa.eu/jrc/en/publication/eurscientific-and-technical-research-reports/digcomp-21-digital-competenceframework-citizens-eight-proficiency-levels-and-examples-use. (accessed November 8, 2021).

Cruz, F. J. F., and Díaz, M. J. F. (2016). Generation z's teachers and their digital skills. comunicar. Med. Educ. Res. J. 24, 97-105. doi: 10.3916/C46-2016-10

Delcker, J., and Ifenthaler, D. (2021). Teachers' perspective on school development at german vocational schools during the covid-19 pandemic. Technol. Pedagogy Educ. 30, 125-139. doi: 10.1080/1475939X.2020.1857826

DESI (2018a). Country Report Romania. Available online at: https://ec.europa. eu/information_society/newsroom/image/document/2018-20/ro-desi_2018country-profile_eng_199394CB-B93B-4B85-C789C5D6A54B83FC_52230.pdf (accessed January 16, 2021).

DESI (2018b). The Digital Economy and Society Index. Available online at: https: //ec.europa.eu/digital-single-market/en/desi (accessed January 16, 2021).

Digital Skills Accelerator (n.d.). ONLINE SELF-ASSESSMENT TOOL. Digital Skills Accelerator. Available online at: https://www.digitalskillsaccelerator.eu/ learning-portal/online-self-assessment-tool/ (accessed December 26, 2021).

Drossel, K., Eickelmann, B., and Gerick, J. (2017). Predictors of teachers' use of ICT in school-the relevance of school characteristics, teachers' attitudes, and teacher collaboration. Educ. Inform. Technol. 22, 551-573. doi: 10.1007/s10639-0169476-y

Edelhauser, E., and Lupu-Dima, L. (2020). Is romania prepared for elearning during the covid-19 pandemic? Sustainability 12:5438. doi: 10.3390/ sul2135438

Engen, B. K. E., and Engen, B. K. (2019). Understanding social and cultural aspects of teachers' digital competences. Comunicar. Med. Educ. Res. J. 27:2019. doi: 10.3916/C61-2019-01

Eroğlu, M., and Şenol, C. (2021). Emergency remote education experiences of teachers during the covid-19 pandemic: a phenomenological research. Education 9, 161-172. doi: 10.34293/education.v9i3.3918

Eurostat (2020). GDP Per Capita in EU Regions. Available online at: https://ec.europa.eu/eurostat/documents/2995521/10474907/1-05032020AP-EN.pdf/81807e19-e4c8-2e53-c98a-933f5bf30f58 (accessed September 17, 2020).

Fernandez-Cruz, F.-J., and Fernandez-Diaz, M.-J. (2016). Teachers' generation $\mathrm{Z}$ and their digital skills. Comunicar. Media Education Research Journal 46, $97-105$.

Fu, J. (2013). The complexity of ICT in education: a critical literature review and its implications. Int. J. Educ. Dev. Using ICT 9, 112-125.

Furman, M., De Angelis, S., Dominguez Prost, E., and Taylor, I. (2019). Tablets as an educational tool for enhancing preschool science. Int. J. Early Years Educ. 27, 6-19. doi: 10.1080/09669760.2018.1439368

Ghavifekr, S., and Quan, T. Y. (2020). "Effect of administration support on teachers' ICT utilization in the Malaysian context," in Utilizing Technology, Knowledge, and Smart Systems in Educational Administration and Leadership, ed. M. Durnali (Hershey, PA: IGI Global), 279-297. doi: 10.4018/978-1-79981408-5.ch015

Ghavifekr, S., and Rosdy, W. A. (2015). Teaching and learning with technology: effectiveness of ICT integration in schools. Int. J. Res. Educ. Sci. 1, 175-191. doi: $10.21890 /$ ijres.23596

Ghavifekr, S., Kunjappan, T., Ramasamy, L., and Anthony, A. (2016). Teaching and learning with ICT tools: issues and challenges from teachers' perceptions. Malaysian Online J. Educ. Technol. 4, 38-57.

Ghavifekr, S., Razak, A. Z. A., Ghani, M. F. A., Ran, N. Y., Meixi, Y., and Tengyue, Z. (2014). ICT integration in education: Incorporation for teaching \& learning improvement. Malaysian Online J. Educ. Technol. 2, 24-45.
Gil-Flores, J., Rodríguez-Santero, J., and Torres-Gordillo, J.-J. (2017). Factors that explain the use of ICT in secondary-education classrooms: the role of teacher characteristics and school infrastructure. Comput. Hum. Behav. 68, 441-449. doi: $10.1016 /$ j.chb.2016.11.057

Gu, X., Zhu, Y., and Guo, X. (2013). Meeting the "digital natives": understanding the acceptance of technology in classrooms. J. Educ. Technol. Soc. 16, 392-402.

Gudmundsdottir, G. B., and Hatlevik, O. E. (2018). Newly qualified teachers' professional digital competence: implications for teacher education. Eur. J. Teacher Educ. 41, 214-231. doi: 10.1080/02619768.2017.1416085

Guo, J., Parker, P. D., Marsh, H. W., and Morin, A. J. (2015). Achievement, motivation, and educational choices: a longitudinal study of expectancy and value using a multiplicative perspective. Dev. Psychol. 51:1163. doi: 10.1037/ a0039440

Hamzah, N. H., Nasir, M. K. M., and Wahab, J. A. (2021). The effects of principals' digital leadership on teachers' digital teaching during the covid-19 pandemic in malaysia. J. Educ. E Learn. Res. 8, 216-221. doi: 10.20448/journal.509.2021.82. 216.221

Hatos, A. (2019). The Impact of digitalization on educational achievement: a literature review from a sociological perspective. Quality Life Calitatea Vietii 30, 3-16.

Heitink, M., Voogt, J., Verplanken, L., van Braak, J., and Fisser, P. (2016). Teachers' professional reasoning about their pedagogical use of technology. Comput. Educ. 101, 70-83. doi: 10.1016/j.compedu.2016.05.009

Hofer, S. I., Nistor, N., and Scheibenzuber, C. (2021). Online teaching and learning in higher education: lessons learned in crises. Comput. Hum. Behav. 121:106789. doi: 10.1016/j.chb.2021.106789

Holotescu, C., Grosseck, G., and Andone, D. (2020). "Report on ICT in education in Romania," in Comparative Analysis of ICT in Education Between China and Central and Eastern European Countries, eds D. Liu, R. Huang, B. Lalic, H. Zeng, and N. Zivlak (Singapore: Springer), 303-323. doi: 10.1007/978-981-156879-4_15

Hootsuite, and Social, W. A. (2019). Digital 2019 Global Digital Overview. Available online at: https://datareportal.com/reports/digital-2019-globaldigital-overview (accessed September 17, 2020).

Hu, X., Gong, Y., Lai, C., and Leung, F. K. S. (2018). The relationship between ICT and student literacy in mathematics, reading, and science across 44 countries: a multilevel analysis. Comput. Educ. 125, 1-13. doi: 10.1016/j.compedu.2018.05. 021

Huang, F., Teo, T., and Guo, J. (2021). Understanding english teachers' nonvolitional use of online teaching: a chinese study. System 101:102574. doi: 10.1016/j.system.2021.102574

Huang, Y. M., and Liang, T. H. (2015). A technique for tracking the reading rate to identify the e-book reading behaviors and comprehension outcomes of elementary school students. Br. J. Educ. Technol. 46, 864-876. doi: 10.1111/bjet. 12182

Huda, I., Yulisman, H., Intan, E., Nurina, C., Erni, F., and Abdullah, D. (2018). Investigating pre-service teachers about their competences, experiences, and attitudes towards technology integration. JPhCS 1114:012033. doi: 10.1088/ $1742-6596 / 1114 / 1 / 012033$

Ifinedo, E., Rikala, J., and Hämäläinen, T. (2020). Factors affecting nigerian teacher educators' technology integration: considering characteristics, knowledge constructs, ICT practices and beliefs. Comput. Educ. 146:103760. doi: 10.1016/ j.compedu.2019.103760

INS (2018). România in Cifre. Breviar Statistic 2018. Available online at: https: //insse.ro/cms/files/publicatii/Romania_in_cifre_breviar_statistic_2018.pdf (accessed June 11, 2021).

Isteniè, A. (2021). Online learning under COVID-19: re-examining the prominence of video-based and text-based feedback. Educ. Technol. Res. Dev. [Epub ahead of print]. doi: 10.1007/s11423-021-09955-w

Janssen, J., Stoyanov, S., Ferrari, A., Punie, Y., Pannekeet, K., and Sloep, P. (2013). Experts' views on digital competence: commonalities and differences. Comput. Educ. 68, 473-481. doi: 10.1016/j.compedu.2013.06.008

Juhaňák, L., Zounek, J., Zaleska, K., Bárta, O., and Vlčková, K. (2019). The relationship between the age at first computer use and students' perceived competence and autonomy in ICT usage: a mediation analysis. Comput. Educ. 141:103614. doi: 10.1016/j.compedu.2019.103614

Karakose, T., Polat, H., and Papadakis, S. (2021a). Examining Teachers' Perspectives On School Principals' Digital Leadership Roles And Technology 
Capabilities During The Covid-19 Pandemic. Sustainability 13:13448. doi: 10. 3390/su132313448

Karakose, T., Yirci, R., Papadakis, S., Ozdemir, T. Y., Demirkol, M., and Polat, H. (2021b). Science mapping of the global knowledge base on management, leadership, and administration related to covid-19 for promoting the sustainability of scientific research. Sustainability 13:9631. doi: 10.3390/ sul3179631

Kesharwani, A. (2020). Do (how) digital natives adopt a new technology differently than digital immigrants? A longitudinal study. Inform. Manage. 57:103170. doi: $10.1016 /$ j.im.2019.103170

Khokhar, A. J., and Javaid, S. (2016). "Students and teachers' perceptions of ICT use in the classroom: pakistani classrooms," in Proceeding of the The Asian Conference on Technology in the Classroom.

Klapproth, F., Federkeil, L., Heinschke, F., and Jungmann, T. (2020). Teachers' experiences of stress and their coping strategies during covid-19 induced distance teaching. J. Pedagogical Res. 4, 444-452. doi: 10.33902/JPR.2020062805

Koen, S., Dirk, S., and Gary, B. (2017). Rural development in the digital age: a systematic literature review on unequal ICT availability, adoption, and use in rural areas. J. Rural Stud. 54, 360-371. doi: 10.1016/j.jrurstud.2015.09.001

König, J., Jäger-Biela, D. J., and Glutsch, N. (2020). Adapting to online teaching during COVID-19 school closure: teacher education and teacher competence effects among early career teachers in Germany. Eur. J. Teacher Educ. 43, 608-622. doi: 10.1080/02619768.2020.1809650

Lam, S.-F., Jimerson, S., Wong, B. P., Kikas, E., Shin, H., Veiga, F. H., et al. (2014). Understanding and measuring student engagement in school: the results of an international study from 12 countries. School Psychol. Quart. 29:213. doi: $10.1037 / \mathrm{spq} 0000057$

Law, N., Pelgrum, W. J., and Plomp, T. (2008). Pedagogy and ICT Use in Schools Around the World: Findings From the IEA SITES 2006 Study, Vol. 23. Berlin: Springer Science \& Business Media. doi: 10.1007/978-1-4020-8928-2

Lim, F. (2020). Digital Learning in the Time of a Pandemic. Education Research for Teachers.

Lucas, M., Bem-Haja, P., Siddiq, F., Moreira, A., and Redecker, C. (2021). The relation between in-service teachers' digital competence and personal and contextual factors: what matters most? Comput. Educ. 160:104052. doi: 10. 1016/j.compedu.2020.104052

Maderick, J. A., Zhang, S., Hartley, K., and Marchand, G. (2016). Preservice teachers and self-assessing digital competence. J. Educ. Comput. Res. 54, 326351. doi: $10.1177 / 0735633115620432$

Majumdar, S. (2015). Emerging Trends in ICT for Education \& Training. Gen. Asia Pac. Reg. IVETA.

Malik, R. S. (2018). Educational challenges in 21st century and sustainable development. J. Sust. Dev. Educ. Res. 2, 9-20. doi: 10.17509/jsder.v2i1.12266

Maněnová, M., Wolf, J., Skutil, M., and Vítová, J. (2021). Combating the coronavirus pandemic in small schools. Sustainability 13:7086. doi: 10.3390/ su13137086

Mâță, L., Clipa, O., and Tzafilkou, K. (2020). The development and validation of a scale to measure university teachers' attitude towards ethical use of information technology for a sustainable education. Sustainability 12:6268. doi: 10.3390/ su12156268

Mazziotta, M., and Pareto, A. (2012). "A non-compensatory approach for the measurement of the quality of life," in Quality of Life in Italy, eds F. Maggino and G. Nuvolati (Dordrecht: Springer), 27-40. doi: 10.1007/978-94-007-3898-0_3 MCSI (2011). Proiectul RO-NET. Bucharest: Romanian Government.

MEC (2014-2020). "CRED-curriculum relevant, educaţie deschisă pentru toţi" cod SMIS 2014+:118327," in Proiect Cofinanţat Din Fondul Social European Prin Programul Operațional Capital Uman 2014-2020. https://www.educred.ro/ (accessed November 8, 2021).

Meyer, B., and Bo-Kristensen, M. (2012). "The digital school: developing teacher competences," in Proceeding of the International Conference one-Learning.

Mingo, I., and Bracciale, R. (2018). The matthew effect in the italian digital context: the progressive marginalization of the "poor". Soc. Indic. Res. 135, 629-659. doi: 10.1007/s11205-016-1511-2

Misheva, G. (2021). Digital Skills Accelerator Self-Assessment Tool. European eLearning Institute (EUEI).

Napal-Fraile, M., Peñalva-Vélez, A., and Mendióroz Lacambra, A. M. (2018). Development of digital competence in secondary education teachers' training. Educ. Sci. 8:104. doi: 10.3390/educsci8030104
Noronha-Sousa, D., Costa, E., Mateus, C., Noronha, A. R., and Vasquez-Justo, E. (2022). "Contemporary education, technologies, and human connectivity: from native generations to digital immigrants," in Perspectives and Trends in Education and Technology, eds A. Mesquita, A. AbreuJoão and V. Carvalho (Singapore: Springer), 973-986. doi: 10.1007/978-981-16-5063-5_80

Noveanu, E., Potolea, D., Simona, V., Petre, B., Cornelia, N., and Olimpius, I. (2008). Informatizarea Sistemului De Invãţãmânt: Programul S.E.I. Bucharest: $\epsilon$ learning.Romania.

OECD (2019a). OECD Skills Outlook 2019. Paris: Thriving In a Digital World. OECD Publishing.

OECD (2019b). PISA 2018 Results (Volume I): What Students Know and Can Do. Paris: OECD Publishing, doi: 10.1787/5f07c754-en

OECD (2019c). PISA 2018 Results (Volume II): Where All Students Can Succeed. Paris: OECD Publishing, doi: 10.1787/b5fd1b8f-en

OECD (2019d). PISA 2018 Results (Volume III): What School Life Means for Students' Lives. Paris: OECD Publishing, doi: 10.1787/acd78851-en

OECD (2019e). PISA 2018 results. combined executive summaries. J. Chem. Inform. Mod. 53, 1689-1699. doi: 10.1017/CBO9781107415324.004

OECD (2020a). Global Teaching Insights. Paris: OECD Publishing.

OECD (2020b). Rural Well-Being. OECD iLibrary. doi: 10.1787/d25cef80-en

OECD (2020c). VET in A Time of Crisis: Building Foundations for Resilient Vocational Education and Training Systems. Available online at: https://read.oecd-ilibrary.org/view/?ref=132_132718-fdwmrqsgmy\&title= VET-in-a-time-ofcrisis-Building-foundations-for-resilient-vocationaleducation-and-training-systems (accessed December 22, 2020).

Orser, B. J., and Riding, A. (2018). The influence of gender on the adoption of technology among SMEs. Int. J. Entrepreneur. Small Bus. 33, 514-531. doi: 10.1504/IJESB.2018.090341

Paniagua, A., and Istance, D. (2018). Teachers as Designers of Learning Environments: The Importance of Innovative Pedagogies. Educational Research and Innovation. Paris: ERIC. doi: 10.1787/g272b194c2-en

Pavić, D., and Černja, I. (2019). How to measure digital literacy? A case of croatian adult learners. Future Inform. Sci. 222, 222-229. doi: 10.17234/INFUTURE. 2019.27

Philipson, I. (1985). Gender and narcissism. Psychol. Women Quart. 9, 213-228. doi: 10.1111/j.1471-6402.1985.tb00873.x

Porat, E., Blau, I., and Barak, A. (2018). Measuring digital literacies: junior highschool students' perceived competences versus actual performance. Comput. Educ. 126, 23-36. doi: 10.1016/j.compedu.2018.06.030

Redecker, C., and Punie, Y. (2017). European framework for the digital competence of educators: digcompedu. Publications Office.

Røkenes, F. M., and Krumsvik, R. J. (2014). Development of student teachers' digital competence in teacher education. a literature review. Nordic J. Digital Literacy 9, 250-280. doi: 10.18261/ISSN1891-943X-2014-04-03

Rucsanda, M. D., Belibou, A., and Cazan, A.-M. (2021). Music teaching and learning in higher education during the COVID lockdown. Front. Psychol. 6017:753785. doi: 10.3389/fpsyg.2021.753785

Saavedra, J. (2020). Educational Challenges and Opportunities of the Coronavirus (COVID-19) Pandemic. World Bank Blogs.

Šabić, J., Baranović, B., and Rogošić, S. (2021). Teachers' self-efficacy for using information and communication technology: the interaction effect of gender and age. Inform. Educ. doi: 10.15388/infedu.2022.11

Santi, E. A., Gorghiu, G., and Pribeanu, C. (2020). Teachers' perceived self-efficacy for mobile teaching and learning. Romanian J. Multid. Educ. Rev. Roman. Pentru Educ. Multid. 12, 157-166. doi: 10.18662/rrem/12.1sup2/259

Saxena, M. K. (2014). A study of computer anxiety among prospective teachers. Int. J. Multid. Educ. Res. 3:123.

Saxena, M. K., Kumar, S., and Singh, A. (2019). Computer anxiety and individual failure in computer usage among teacher educators of universities and colleges: a study on FDP participants. Int. J. Inform. Dissem. Technol. 9, 191-195. doi: 10.5958/2249-5576.2019.00037.2

Schleicher, A. (2020). The Impact Of Covid-19 On Education Insights From Education At A Glance 2020. Available online at: Retrieved from: https://www.oecd.org/education/the-impact-of-covid-19-oneducation-insights-education-at-a-glance-2020.pdf (accessed June 11, 2021).

Shonfeld, M., Aharony, N., and Kritz, N. (2020). "The impact of participating in a digital program on teachers' perceptions of their information literacy," 
in Proceeding of the Society for Information Technology \& Teacher Education International Conference. doi: 10.1177/09610006211026950

Shrauger, J. S., and Osberg, T. M. (1981). The relative accuracy of self-predictions and judgments by others in psychological assessment. Psychol. Bull. 90:322. doi: 10.1037/0033-2909.90.2.322

Simuţ, C., Petrila, L., Popescu, F.-A., and Oprea, I. M. (2021). Challenges and opportunities for telecommuting in the school system: building a sustainable online education in the context of the SARS-Cov-2 pandemic. Sustainability 13:10296. doi: 10.3390/su131810296

Starčič, I. A., Cotic, M., Solomonides, I., and Volk, M. (2016). Engaging preservice primary and preprimary school teachers in digital storytelling for the teaching and learning of mathematics. Br. J. Educ. Technol. 47, 29-50. doi: 10.1111/bjet. 12253

Sundqvist, K., Korhonen, J., and Eklund, G. (2020). Predicting finnish subject teachers ICT use in home economics based on teacher-and school-level factors. Educ. Inquiry 12, 1-21. doi: 10.1080/20004508.2020.1778609

Tanhua-Piiroinen, E., Viteli, J., Syvänen, A., Vuori, J., Hintikka, K., and Sairanen, H. (2016). Perusopetuksen Oppimisympäristöjen Digitalisaation Nykytilanne Ja Opettajien Valmiudet Hyödyntää Digitaalisia Oppimisympäristöjä [The Current State of Digitalisation Of Learning Environments In Basic Education And Teachers' Ability To Take Advantage Of Digital Learning Environments] (Publications of the Government's Analysis, Assessment And Research Activities 18/2016. Prime Minister's Office

Tasir, Z., Abour, K. M., Halim, N. D. A., and Harun, J. (2012). Relationship between teachers' ICT competency, confidence level, and satisfaction toward ICT training programmes: a case study among postgraduate students. Turkish Online J. Educ. Technol. 11, 138-144.

Van Dijk, J. A. (2020). The Digital Divide. Cambridge: John Wiley \& Sons.

Van Mechelen, M., Wagner, M.-L., Baykal, G. E., Charlotte Smith, R., and Iversen, O. S. (2021). Digital design literacy in k-9 education: experiences from pioneer teachers. Int. Design Child. 32-42. doi: 10.1145/3459990.3460696

Vasileva-Stojanovska, T., Malinovski, T., Vasileva, M., Jovevski, D., and Trajkovik, V. (2015). Impact of satisfaction, personality, and learning style on educational outcomes in a blended learning environment. Learn. Indiv. Differ. 38, 127-135. doi: 10.1016/j.lindif.2015.01.018

Veiga, F., Galvão, D., Almeida, A., Carvalho, C., Janeiro, I., Nogueira, J., et al. (2012). "Students' engagement in school: a literature review," in Proceeding of the 5th International Conference of Education, Research, and Innovation-ICERI.

West, M., Kraut, R., and Ei Chew, H. (2019). I'd Blush if I Could: Closing Gender Divides in Digital Skills Through Education. San Borja: Ministerio de Educacion.

Wiesel, I., and Liu, F. (2020). Conceptualizing modes of redistribution in public urban infrastructure. Urban Stud. 58, 1561-1580. doi: 10.1177/ 0042098020913188
Willems, P. P., Gonzalez-DeHass, A. R., Powers, J. R., and Musgrove, A. (2021). The role of authentic teaching cases and mastery approach goals in online pre-service teachers' self-regulated learning. Educ. Technol. Re. Dev. 69, 1-21. doi: 10.1007/s11423-021-09972-9

Winstone, N. E., Hepper, E. G., and Nash, R. A. (2021). Individual differences in self-reported use of assessment feedback: the mediating role of feedback beliefs. Educ. Psychol. 7, 844-862. doi: 10.1080/01443410.2019.169 3510

Wong, K. Y., Sulaiman, T., Ibrahim, A., Mohd, A. G. K., Hassan, O., and Jaafar, W. M. (2021). Secondary school teachers' psychological status and competences in e-teaching during Covid-19. Heliyon 7:e08238. doi: 10.1016/j.heliyon.2021. e08238

Wu, D., Zhou, C., Li, Y., and Chen, M. (2022). Factors associated with teachers' competence to develop students' information literacy: a multilevel approach. Comput. Educ. 176:104360. doi: 10.1016/j.compedu.2021.10 4360

Yang, Z., Barnard-Brak, L., and Siwatu, K. (2019). How does the availability of information and communication technology (ICT) resources mediate the relationship between socioeconomic status and achievement? J. Technol. Behav. Sci. 4, 262-266. doi: 10.1007/s41347-018-0079-x

Yevelson-Shorsher, A., and Bronstein, J. (2018). Three perspectives on information literacy in academia: talking to librarians, faculty, and students. College Res. Libraries 79:535. doi: 10.5860/crl.79.4.535

Zenios, M., and Ioannou, E. (2018). "Digital natives and digital immigrants revisited: a case of CALL," in Proceeding of the International Conference on Learning and Collaboration Technologies. doi: 10.1007/978-3-319-91152-6_8

Conflict of Interest: The authors declare that the research was conducted in the absence of any commercial or financial relationships that could be construed as a potential conflict of interest.

Publisher's Note: All claims expressed in this article are solely those of the authors and do not necessarily represent those of their affiliated organizations, or those of the publisher, the editors and the reviewers. Any product that may be evaluated in this article, or claim that may be made by its manufacturer, is not guaranteed or endorsed by the publisher.

Copyright $\odot 2022$ Hatos, Cosma and Clipa. This is an open-access article distributed under the terms of the Creative Commons Attribution License (CC BY). The use, distribution or reproduction in other forums is permitted, provided the original author(s) and the copyright owner(s) are credited and that the original publication in this journal is cited, in accordance with accepted academic practice. No use, distribution or reproduction is permitted which does not comply with these terms. 